\title{
Updates on the legal front
}

\author{
Andrew D. Cardon, Matthew R. Bailey \& B. Taylor Bennett
}

Lawyers within the animal rights movement have been working for years to lay the groundwork and test new legal theories in a focused and determined effort to grant additional legal protections for animals, including animals involved in research. These efforts have included expanding state animal cruelty laws, working to increase access to federal courts by eliminating standing requirements and eventually establishing a form of 'legal personhood' for some species of animals, either legislatively or through the courts. The granting of legal personhood to a species of animal would not only change its legal status under the law but also likely mean the animals would no longer be used in research.

The first lawsuits seeking to establish legal personhood for chimpanzees were filed in December 2013 by a US animal rights group. In three separate lawsuits, one of which was filed against a state research university, the Nonhuman Rights Project asked New York state courts to grant "the immediate release" of the chimpanzees and recognize their "common law right to the bodily liberty protected by the common law writ of habeas corpus"1. A petition for a writ of habeas corpus allows a person to challenge their unlawful detention. The basis for the claims rests on state laws allowing animals to be trust beneficiaries; research into the cognitive complexity of chimpanzees; common law habeas corpus cases; and guidelines for the care of chimpanzees, including the US National Institutes of Health (NIH) recommendations concerning the use of chimpanzees in NIH-supported research.

The cases faced an uphill battle, as they were seeking a significant expansion of the law, and were quickly dismissed. All three are now being appealed, however, and, if the appeals are successful, the decisions could affect biomedical research, as the right to bodily liberty would preclude the use of such animals in research. In combination with other ongoing legislative and public relations campaigns, legal efforts are likely to play a key role in attempts to end the use of animals in research.

In other legal news, animal rights activists have continued to challenge the constitutionality of the Animal Enterprise Terrorism Act (AETA), the only federal law specifically designed to protect animal research facilities ${ }^{2}$. In early February, the US Court of Appeals for the First Circuit held a hearing on the appeal of Blum v. Holder, a federal lawsuit in which five activists are alleging that the law is unconstitutional. The lawsuit was dismissed on 18 March 2013, after the US District Court in the District of Massachusetts found the activists lacked standing to challenge the law ${ }^{3}$.

The activists' challenge rested on their asserted fear of prosecution for engaging in First Amendment-protected activities, such as protesting or letter-writing campaigns. The District Court determined that lawful advocacy is not prohibited by the AETA and found the activists had no standing to challenge the constitutionality of the law, since they failed to indicate an "intention to engage in any activity 'that could reasonably be construed' to fall within the statute."

The National Association for Biomedical Research, joined by eleven other organizations, filed an amicus brief in the original suit. Individual researchers who had been targeted by animal rights extremists also filed an amicus brief. The amicus brief supported the government's motion to dismiss the case and urged the court to find the AETA constitutional.

In February 2014, a three-judge panel consisting of Chief Judge Sandra L. Lynch, Judge O. Rogeriee Thompson and Judge William J. Kayatta Jr. conducted a 30-minute hearing on the appeal. Given their early and continued questioning, the judges clearly had read and considered the written arguments made by both sides.

Chief Judge Lynch's questions primarily focused on the activists' standing to challenge the AETA after the recent Supreme Court decision in Clapper $v$. Amnesty, which ruled that a plaintiff must show certainly impending harm in order to have standing 4 . Attorneys for the activists focused on the merits of the law in their arguments. The judges did not indicate when a final decision would be reached.

1. The Nonhuman Rights Project v. State University of New York at Stony Brook, Index No. 13-32098, State of New York Supreme Court, County of Suffolk (2 December 2013).

2. 18 U.S.C. § 43.

3. Blum et al. v. Holder, Case No. 11-cv-12229, US District Court for the District of Massachusetts (18 March 2013).

4. Clapper et al. v. Amnesty International et al. 133 S.Ct. 1138 (2013). 